\title{
Topoisomerase I suppresses genomic instability by preventing interference between replication and transcription
}

\author{
Sandie Tuduri, Laure Crabbé, Chiara Conti, Hélène Tourrière, Heidi Holtgreve-Grez, Anna Jauch, Véronique \\ Pantesco, John De Vos, Aubin Thomas, Charles Theillet, Yves Pommier, Jamal Tazi, Arnaud Coquelle and \\ Philippe Pasero
}

Nat. Cell Biol. 11, DOI: 10.1038/ncb1984; published online 18 October 2009

The source of diospyrin (D1) was not stated. D1, isolated from Diospyros montana Roxb. [B. Hazra, et al., Planta Medica, 51(1984) 295-7], was a gift from Banasri Hazra, Jadavpur University, Kolkata, India, to Jamal Tazi, one of the authors of this paper. 